УДК 336:331.1.

Стащук Олена, докторка економічних наук, професорка, Волинський національний університет імені Лесі Українки, завідувачка кафедри фінансів м. Луцьк; ORCID ID 0000-0003-2622-7353 e-mail:Staschuk.Olena@vnu.edu.ua

Проць Наталія, кандидатка економічних наук, доцентка кафедри фінансів,

Волинський національний університет імені Лесі Українки, м. Луцьк; ORCID ID 0000-0001-9483-8987 e-mail: Vyshnevska.Nataliya@vnu.edu.ua

https://doi.org/10.29038/2786-4618-2021-02-79-86

\title{
ПРОБЛЕМИ І ПЕРСПЕКТИВИ ЗДІЙСНЕННЯ БЮДЖЕТНОГО КОНТРОЛЮ ПУБЛІЧНИХ ЗАКУПІВЕЛЬ В УКРАЇНІ
}

В статті аналізуються існуючі проблеми проведення бюджетного контролю публічних закупівель в Україні в сучасних умовах, не вирішені питання здійснення публічних закупівель після вступу в дію нової редакції Закону України «Про публічні закупівлі», досліджуються проблеми у діяльності учасників тендерів, виявлені можливі втрати для економіки нашої країни у випадку запровадження законопроєкту про локалізацію публічних закупівель в Україні, обгрунтовані перспективні шляхи вирішення існуючих проблем у проведенні публічних закупівель у нашій країні з урахуванням світового досвіду.

Ключові слова: публічні закупівлі, бюджетний контроль, тендерні процедури, учасники публічних закупівель, вартість життєвого циклу, локалізація публічних закупівель, Україна, ЄС.

Стащук Елена, доктор экономических наук, профессор, Волынский национальный университет имени Леси Украинки заведующая кафедрой финансов, г. Луцк,

Проць Наталия, кандидат экономических наук, доцент, Волынский национальный университет имени Леси Украинки доцент кафедры финансов, г. Луцк,

\section{ПРОБЛЕМЫ И ПЕРСПЕКТИВЫ ОСУЩЕСТВЛЕНИЯ БЮДЖЕТНОГО КОНТРОЛЯ ПУБЛИЧНЫХ ЗАКУПОК В УКРАИНЕ}

В статье анализируются существующие проблемы проведения бюджетного контроля публичных закупок в Украине в современных условиях, нерешенные вопросы осуществления публичных закупок после вступления в силу новой редакции Закона Украины «О публичных закупках», исследуются проблемы у деятельности участников тендеров, выявлены возможные потери для экономики нашей страны в случае введения в действие законопроекта о локализации публичных закупок в Украине, обоснованы перспективные пути решения существующих проблем в проведении публичных закупок в нашей стране с учетом мирового опыта.

Ключевые слова: публичные закупки, бюджетный контроль, тендерные процедуры, участники публичных закупок, стоимость жизненного цикла, локализация публичных закупок, Украина, ЕС. 


\section{Olena Stashchuk, Doctor of economics, Professor, Lesya Ukrainka Volyn National University,Department of Finance} Lutsk

Prots Natalia, Ph. D. in Economic sciences, Associate Professor Lesya Ukrainka Volyn National University,Department of Finance Lutsk

\section{PROBLEMS AND PROSPECTS OF BUDGETARY CONTROL OF PUBLIC PROCUREMENT IN UKRAINE}

\section{Annotation.}

Introduction. The article analyzes the existing problems of budgetary control of public procurement in Ukraine in modern conditions, unresolved issues of public procurement after the entry into force the new version of the Law of Ukraine "On Public Procurement", examines the problems of bidders and customers, analyzes strengths and weaknesses in the activities of state control structures for conducting tender procedures, possible losses for the economy of our country in the case of the introduction the bill on the localization of public procurement in Ukraine.

Results. Promising direction for the development of public procurement in Ukraine should be the improvement of the Prozorro system and its supplementation with various forms of public control over the conduct of these procurements at all levels. It is proved that a promising direction in the development of public procurement is also the improvement of the Prozorro Market system. The problem is that public control in the field of public procurement is not yet widespread in Ukraine. This is hindered by the lack of financial literacy of the majority citizens, which should be increased through the development of all possible forms of education. Improving the efficiency of the use of public finances in Ukraine requires a significant improvement in the training of staff in budget organizations that generate budget inquiries, as many of them do not have the appropriate education and experience.

Significant problem remains the fact that the main indicator for the field of public procurement is still the price, and the indicator of the life cycle of goods is almost not used (as well as other non-price criteria). A difficult problem when applying the cost of the life cycle of goods in public procurement is that the customer independently decides on the feasibility of using it to evaluate tenders. He also chooses the types of costs that are important to him, which will be taken into account when calculating the cost of the life cycle of goods.

Conclusions.To strengthen financial control in the field of public procurement, it would be appropriate to use more widely non-price criteria, which are measured not only by the difference between the expected cost of procurement, but also the environmental friendliness of the subject of procurement in the broadest sense. A promising area of public procurement regulation may be the improvement of financial control mechanisms and identify all costs when evaluating the cost of the product life cycle, but it requires substantial retraining customers of the tender.

Promising ways to solve existing problems in conducting public procurement in our country, taking into account world experience is substantiated in the article. The mechanism of public procurement in Ukraine must be adapted primarily to EU requirements, which will allow our country in the future to raise questions about joining this organization. This is contradicted by the desire of many government officials and big business to adopt a law on the localization of public procurement in Ukraine, which is contrary to EU norms.

Key words: public procurement, budget control, tender procedures, participants of public procurement, cost of life cycle, localization of public procurement, Ukraine, EU.

Постановка проблеми у загальному вигляді i ïi зв'язок 3 важливими науковими та практичними проблемами. В системі публічних фінансів України з кожним роком зростає роль $\mathrm{i}$ значення роль ринку публічних закупівель, щорічний обсяг якого вже перевищив 700 млрд грн. Тому важливо добитися ефективного використання публічних коштів, виділених на публічні закупівлі в Україні на всіх рівнях, чого поки не вдається досягнути у повній мірі. Навіть запровадження в 2020 р. нової редакції Закону України «Про публічні закупівлі» не вирішило всіх існуючих проблем. Тому важливим завданням удосконалення сфери публічних фінансів у нашій країні є впровадження такого механізму регулювання та контролю публічних закупівель, який би відповідав принципам і нормам, які застосовуються країнами СС, оскільки Україна підписала 3 Свропейським Союзом Угоду про асоціацію. Також необхідно узгодити процес законодавчого 
забезпечення локалізації виробництва окремих товарів в Україні відповідно до вимог міжнародних угод, чого поки не вдається досягнути та може призвести до ускладнення економічних відносин насамперед з $\mathrm{EC}$.

Аналіз останніх досліджень і публікацій. Зараз все більше зарубіжних та українських вчених і практиків шукають нові підходи до вирішення проблем підвищення фінансової ефективності публічних фінансів, оскільки подолання наслідків коронакризи змусило більшість держав світу піти на різке зростання дефіцитів бюджету та державного боргу. Так, за підсумками 2020 р. сукупний світовий борг (борг усіх держав, домогосподарств, фінансових та нефінансових компаній) досяг 355 \% світового ВВП. В Україні сума державного та гарантованого державою боргу зросла з близько 71 млрд дол США в 2016 р. до 90,25 млрд дол США в 2020 р. [1]. Для вирішення цієї проблеми дефіцит Державного бюджету України планується поступово скорочувати: з 5,1 \% ВВП у 2021 р. до 2,7 \% у 2024 р. [2]. Одним із напрямів зменшення державного боргу та оптимізації дефіциту бюджету для нашої країни може стати підвищення ефективності бюджетного контролю проведення публічних закупівель з урахуванням використання досвіду країн $Є С$ з цього питання.

Значний вклад у вивчення теоретичних та практичних проблем проведення публічних закупівель внесли багато зарубіжних і українських вчених. Зокрема, теоретичні та методологічні основи здійснення публічних закупівель у демократичних країнах світу та в Україні дослідили такі зарубіжні та українські вчені, як: Г. Азаренкова, М. Білуха, І. Бондар, А. Бойєр, А. Брендон-Джонс, А. Буряченко, О. Воробйова, В. Геєць, Д. Гелбрейт, В. Горин, А. Давіл, О. Длугопольський, Т. Жибер, Н. Конащук, О. Міщенко, Т. Мороз, В. Морозов, О. Овсянюк-Берладіна, Д. Кауфман, Й. Матечак, А. Олефір, Н. Панайотоу, О. Рижова, І. Сидоренко, Дж. Стігліц, Н. Ткаченко, Г. Харченко, А. Хайнеманн, А. Храмкін, В. Чабан, І. Чорна, Р. Шаппер, О. Шатковський, С. Яременко та ін. Водночас, поглиблений аналіз досвіду здійснення публічних закупівель в Україні в сучасних умовах показує, що наша країна поки має достатньо проблем у цьому питанні, зокрема, що стосуються регулювання «зелених» закупівель та локалізації виробництва. Важливість посилення фінансової відповідальності. Крім того, замовники і учасники публічних закупівель в Україні допускають певні порушення при проведенні тендерів. Тому в Україні необхідно максимально використати досвід країн СС у посиленні відповідальності всіх суб'єктів публічних закупівель та проведення контролюючих заходів.

Мета та завдання статті. Метою статті є розкриття основних особливостей та проблем у здійсненні бюджетного контролю публічних закупівель в Україні і виявити шляхи їх подолання 3 урахуванням досвіду демократичних країн, що дозволить підвищити ефективність використання публічних фінансів нашої країни. Відповідно, завданнями статті $є$ обгрунтування перспективних напрямів проведення публічних закупівель в Україні з урахуванням досвіду країн СС та інших демократичних країн; виявлення проблем у діяльності державних контролюючих структур в Україні, що моніторять публічні закупівлі, та запропонувати шляхи їх вирішення; виявити шляхи гармонізації українського підходу до локалізації публічних закупівель з стандартами $€ С$, інших міжнародних організацій.

Викладення основного матеріалу і обгрунтування отриманих результатів дослідження. Складність вирішення проблеми 3 підвищення ефективності використання публічних фінансів та 3 удосконаленням публічних закупівель в Україні полягає, крім іншого, в тому, що поки існує неоднозначне розуміння поняття «публічні фінанси». Враховуючи, що до складу публічних фінансів сьогодні включають не тільки державний, а й місцеві бюджети, які за українським законодавством $\epsilon$ відносно самостійними утвореннями, то замість категорії «державні фінанси», доцільно використовувати термін «публічні фінанси», як це робиться у підручниках з фінансів у багатьох країнах світу. Зокрема, у підручниках 3 публічних фінансів, написаних відомими польськими вченими: Станіславом Овсяком [2, с. 19], Сжи Осятинським [4, с. 16], Ельжбєтою МалиновськоюМісьонг та Войцехом Місьонгом [5, с. 33] наголос зроблено на публічні фінанси, а не на державні фінанси, оскільки останні вужчі за змістом, так як не включають місцеві фінанси. У той же час, в Україні до цього часу домінує традиційний підхід до визначення фінансової системи без виділення в ній публічних (суспільних) фінансів. На наш погляд, не можна ототожнювати державні та публічні фінанси, оскільки державні фінанси $є$ складовими публічних фінансів. Подібне стосується й 
визначення публічних закупівель, які включають в себе не тільки державні закупівлі, а й закупівлі органів місцевого самоврядування. Це твердження знайшло відображення й у тому, що тепер відповідний Закон України називається «Про публічні закупівлі».

Аналіз розвитку сфери публічних закупівель в економіках окремих країн $С С$ говорить про їхню значну частку у ВВП цих країн. Зокрема, середній рівень частки публічних закупівель у ВВП країн ЄС у 2012-2018 pp. майже досягнув рівня в 13 \% ВВП, тоді як в Україні цей показник на початок 2018 р. знаходився на рівні 4,6 \%, що у значній мірі пов'язано із частими змінами законодавства [6, c. 9-10]. Водночас, у сфері публічних закупівель у 2018 р. Україна уклала 850 контрактів 3 іноземними компаніями, що свідчило про виконання нею міжнародних угод щодо відкриття українського ринку публічних закупівель. У 2019 р. публічні закупівлі стали найбільшим ринком в Україні, на якому було здійснено більше 1 млн процедур із обігом 700 млрд грн. Аналіз публічних закупівель у 2016-2018 pp., коли запрацювала електронна система Prozorro, показало, що запровадження цієї системи для всіх категорій замовників суттєво збільшило їх обсяги. Так, протягом 2018 р. відбулося суттєве збільшення обсягу публічних закупівель у порівнянні з 2009 р. (у чотири рази). У 2020 р. завдяки Prozorro вдалося заощадити близько 43 млрд грн, що на 43 \% було більше, ніж у 2019 р. Тому перспективним напрямом розвитком публічних закупівель $\epsilon$ удосконалення системи Prozorro. В цьому плані заслуговує на підтримку система Prozorro Market [7]. Вона націлена на те, щоб державі було простіше закуповувати товари на невеликі суми (до 200 тис грн та до 1 млн грн для підприємств-монополістів). Державне підприємство просто обирає на ньому товар із наявних у каталозі позицій. Доступ до каталогу та можливість продавати свої товари отримують попередньо акредитовані компанії. Комісійна оплата нараховується після укладення угоди.

Не дивлячись на позитивні зміни, привнесеними у 2020 р. новою редакцією Закону України «Про публічні закупівлі», суттєвою проблемою залишається той факт, що основним показником для сфери публічних закупівель поки $є$ ціновий, а показник життєвого циклу товару майже не застосовується (як й інші нецінові критерії). Так, у 2018 р. лише у 0,8 \% оголошених процедур закупівель застосовувалися нецінові критерії. Водночас, позитивним моментом стало те, що з 30.04.2021 р. в електронній системі Prozorro можна оголошувати тендерні закупівлі за вартістю життєвого циклу (ВЖЦ), а особливості використання ВЖЦ в якості критерію оцінки тендерних пропозицій зазначені у відповідному наказі Мінекономіки № 1894 за 2021 р. «Про затвердження Примірної методики визначення вартості життєвого циклу» [8]. Хоча ця методика не є обов'язковою, але вона, на наш погляд, зможе допомогти замовникам ефективно застосовувати новий критерій оцінки тендерних пропозицій. Вказаною методикою визначені наступні види витрат, що можуть використовуватися під час розрахунку ВЖЦ. До них відносяться: витрати, пов'язані з придбанням (витрати, які безпосередньо впливають на ціну предмету закупівлі та включають його вартість, вартість доставки, установлення тощо); витрати, пов'язані 3 користуванням (вартість споживання електроенергії, природного газу, пального або інших ресурсів, необхідних для функціонування предмету закупівлі); витрати, пов'язані з обслуговуванням (вартість гарантійного обслуговування, вартість заміни окремих запасних частин, навчання персоналу тощо); витрати, пов'язані із завершенням користування (вартість транспортування до компанії з утилізації відходів, вартість переробки та утилізації відходів тощо). При розрахунках останніх витрат треба мати на увазі, що з в перспективі вартість переробки, утилізації та захоронення відходів в Україні буде стрімко зростати, оскільки ці витрати у нашій країні на порядок менше, ніж в країнах ЄС. А це може призвести до накладення суттєвих санкцій з боку ЄС на підприємства нашої країни, які неналежним чином поводяться 3 відходами виробництва.

В умовах запровадження в СС Зеленого енергетичного курсу, вважаємо за доцільне, щоб Україна активніше використовувала так звані «зелені» публічні закупівлі, щоб не попасти в майбутньому під санкції Європейського Союзу, який з 2023 р. може застосувати набагато жорсткіші «зелені» вимоги до багатьох видів товарів, що сьогодні Україна експортує до ЄС. Хоча у вказаній вище методиці при розрахунку витрат, пов'язаних з ВЖЦ, передбачені витрати, націлені на захист навколишнього середовища (плата за викиди окремих забруднюючих речовин в атмосферне повітря, грунти, воду тощо), але у ній не враховано той факт, що вказані витрати в Україні будуть стрімко зростати під 
тиском ЄС. Останній передбачив, що підприємства-експортери до Європейського Союзу (зокрема, й 3 України) у найближчій перспективі будуть сплачувати додатковий вуглецевий податок за так званий вуглецевий слід. Цей показник буде визначатися на основі оцінки кількості використаної енергії, виробленої за допомогою викопних джерел енергії. При цьому підприємства-експортери до ЄC будуть надавати відповідний документ, де все це буде зазначено. Для багатьох українських промислових та сільськогосподарських підприємств це створить серйозні проблеми щодо експорту до ЄС своєї продукції, а Українська держава залишиться без значної суми валютної виручки. Тому важливо і підприємствам, і нашій державі розробити програму прискореної модернізації екологічно шкідливих виробництв-експортерів до Свропейського Союзу, оскільки український експорт до країн ЄС сягає близько 40 \% всього нашого експорту. Важливо для вирішення вказаної проблеми залучити й іноземні інвестиції та «зелені» кредити, а також випустити «зелені облігації», як це роблять КНР, США та ряд інших країн. Водночас самій Українській державі з вирішенням кліматичних проблем не впоратися, оскільки тільки екологічна модернізація металургійної промисловості нашої країни, за підрахунками експертів, вимагатиме більше 100 млрд євро. Загалом, за умови часткового впровадження змін до чинного законодавства, але без структурних змін в енергетиці та економіці в Україні до 2030 р. можна досягти скорочення викидів вуглекислого газу на $54 \%$, але для реалізації цього сценарію потрібно 168 млрд євро інвестицій. При реалізації в Україні сценарію кліматично нейтральної економіки, який передбачає скорочення викидів вуглекислого газу до 2030 р. на 73 \%, потрібно залучити 256 млрд євро. Водночас, в Україні загальний обсяг капітальних інвестицій за 2004-2019 рр. становив 318 млрд євро [9]. У той же час для вирішення проблем потепління клімату та екологічної модернізації промисловості країн $Є С$ ця організація виділяє на наступні роки більше одного трильйона євро. Тому українським підприємствам-експортерам до ЄС важливо розробити такі програми екологічної модернізації, які зацікавлять їх партнерів з країн Європейського Союзу та дозволять отримати за їх допомогою «зелені» інвестиції з фондів СС. Зокрема, в металургійній галузі таким проєктом може стати розвиток електрометалургії, в сільському господарстві - виробництво органічної продукції, в енергетичній галузі - використання водню замість газу.

Складною проблемою при застосуванні вартості життєвого циклу товару (ВЖЦ) при здійсненні публічних закупівель $\epsilon$ те, що замовник самостійно приймає рішення щодо доцільності використання ВЖЦ для оцінки тендерних пропозицій. Також він сам обирає важливі для нього види витрат, що будуть враховані під час розрахунку ВЖЦ. Крім того, замовник має зазначити у своїй тендерній документації методику розрахунку з урахуванням обраних видів витрат. Останнє зробити буде дуже важко, оскільки ні члени тендерних комітетів, ні уповноважені з публічних закупівель у бюджетних організаціях поки не підготовлені належним чином до розрахунків різних видів витрат, що стосуються вартості життєвого циклу товарів. Аналіз реальної практики здійснення публічних закупівель на місцевому рівні показує, що відповідальні за публічні закупівлі у бюджетних організаціях бояться допустити будь-яких помилок при формуванні запиту, оскільки за допущені прорахунки їм особисто прийдеться платити значні штрафи [10]. Крім того, ліквідація тендерних комітетів та запровадження інституту уповноважених з публічних закупівель з 01.01.2020 p. у всіх бюджетних організаціях ставить на порядок денний необхідність організації прискореної підготовки таких фахівців. Особливо це стосується підготовки подібних спеціалістів для новостворених територіальних громад та ЦНАПів у сільській місцевості, оскільки у них зараз не вистачає навіть фінансистів-бюджетників, не кажучи про юристів-фахівців з публічних закупівель. Для вирішення вказаної проблеми було б доцільним розпочати підготовку уповноважених з публічних закупівель на відповідних магістерських програмах у закладах вищої освіти за кошти територіальних громад або за кошти інших зацікавлених юридичних та фізичних осіб, залучаючи на ці програми бажаючих, зокрема й безробітних, з вищою економічною освітою.

При проведенні публічних закупівель в Україні треба враховувати, що поки при їх проведенні існують так звані «відкоти»; зриви у проведенні торгів тими учасниками, які прагнуть перемогти своїх конкурентів або не дати їм можливість прийняти участь в тендері; фінансове шахрайство при проведенні публічних закупівель тощо. Тому важливо підвищити ефективність проведення публічних закупівель та посилити контроль за ними. На це насамперед направлена нова редакція Закону України «Про публічні закупівлі», яка почала діяти з квітня 2020 р. 3 цієї дати всі замовники 
публічних закупівель у нашій країні зобов'язані публікувати в системі Prozorro повну інформацію про всі свої закупівлі. Загалом, у 2020 р. завдяки використанню системи Prozorro державі вдалося заощадити близько 43 млрд грн, що на 43 \% було більше, ніж в 2019 р. [11]. Система Prozorro інтегрована 3 Державним реєстратором лікарських засобів, взаємодіє з Державною фіскальною службою (ДФС) та Державною казначейською службою (ДКС), що зменшує ризики прояву фінансових правопорушень при здійсненні публічних закупівель. Посилення всіх форм контролю за ефективністю публічних закупівель пов'язане ще й з тим, що державні замовники не стільки крадуть, як просто не зацікавлені заощаджувати публічні кошти [11]. Це стало результатом того, що бюджетна сфера зараз побудована так, головне просто витратити всі кошти до Нового року. Саме тому державні замовники більше непокоються тим, як провести всі тендери вчасно, аніж купити якісні товари за найвигіднішою ціною. Для виправлення вказаної ситуації було б доцільним розробити спеціальну систему преміювання для тих, хто готує ефективні тендерні замовлення. Крім того, важливо звільнити працівників ЦНАПів, які ведуть тендери, від інших не властивих їм функцій, як про це свідчить аналіз реальної практики на місцях.

Перспективним напрямом у публічних закупівлях стало й те, що перевірка протягом 2016-2021 pp. перетворилася на самостійну форму здійснення державного контролю, тоді як раніше Державна аудиторська служба включала ії окремими пунктом до програми державного фінансового аудиту та інспектування, не призначала їх перевірки, як самостійну форму контролю. Загалом, у 2018 р. Державна аудиторська служба та Рахункова палата встановили порушення публічних закупівель обсягом 39, 15 млрд грн. У липні 2020 р. Трансперенсі Інтернешнл Україна перевірила скільки надпорогів потрапило у моніторинг Державна аудиторська служби у 2018-2019 рр. і виявила, що аудитори охопили перевірками лише 1,8 \% процедур. Тому доцільним є створення окремої Агенції 3 тендерних закупівель, яка б взяла на себе функцію контролю за здійсненням публічних закупівель (за прикладом Польщі), а не розпорошувати цю функцію між кількома державними структурами, для яких вона $є$ не основною. У Польщі цю функцію виконує національна інспекція контролю [12]. Крім того, важливо ширше долучати до контролю за публічними закупівлями громадські організації, в чому ми також вбачаємо перспективну форму підвищення ефективності публічних закупівель в Україні. В цьому плані заслуговує на увагу діяльність такої громадської організації як DOZORRO. Це - спільнота активістів та громадських організацій по всій Україні, які здійснюють моніторинг публічних закупівель. 26 громадських організацій та понад 1000 волонтерів аналізують та визначають тендери з високим ризиком і подають відповідні скарги до контролюючих органів. Завдяки діяльності DOZORRO понад 9100 публічних торгів з високим ризиком скасували або до них внесли необхідні зміни. Вартість цих торгів склала 906 млн дол США. Загалом, щоб участь громадянського суспільства у контролі за публічними закупівлями (насамперед, на місцях) була ефективною, необхідно інвестувати додаткові кошти у підвищення фінансової грамотності громадян різного віку, а не тільки молоді.

При проведенні публічних закупівель на перспективу Україні важливо дотримуватися міжнародних угод, зокрема із СОТ та СС щодо таких закупівель, інакше вона може попасти під їх санкції. Насамперед це стосується намірів України прийняти закон про локалізацію, який надасть переважні права у публічних закупівлях для окремих українських виробників машинобудівної промисловості. Проблема полягає в тому, що Угода про асоціацію з СС та угода СОТ про публічні закупівлі, як міжнародні договори, мають вищу юридичну силу, ніж закон про локалізацію, який планує прийняти Верховна Рада України (він поки прийнятий у першому читанні). Підписавши Угоду про асоціацію України з СС, наша країна отримала не тільки певні преференції у торгових відносинах з країнами $€ С$, але й зобов'язалася виконувати певні вимоги цього співтовариства. Це стосується й загальних основ законодавства про публічні закупівлі в ЄС. Для цього були прийняті певні законодавчі акти, які гармонізують українське законодавство в сфері публічних закупівель із законодавством Європейського Союзу та СОТ. Зокрема, СС може скористатися своїм правом i використати процедуру урегулювання суперечок з Україною за Угодою про асоціацію, яка в сьогоднішніх умовах буде швидшою і дієвою. У випадку програшу України втратить, крім всього іншого, й фінансову підтримку ЄС з багатьох питань [13]. Серед іншого, слід очікувати: 1) затягування на роки процесу оновлення Угоди про асоціацію, особливо торгової частини; 2) 
розірвання домовленості щодо відкриття ринку електронної комерції («цифровий безвіз»); 3) блокування домовленостей щодо «дзеркального бюджету для України» у рамках участі у Зеленій угоді Європейського Союзу тощо. Можливою відповіддю ЄС може стати й відміна так званого «безвізу» для України. Тому документ про локалізацію вимагає або суттєвого доопрацювання, або зняття з розгляду Верховною Радою України. Для вирішення існуючих суперечностей з СС у царині локалізації публічних закупівель у нашій країні було б доцільним, як пропонується окремими експертами [14, с. 161], створювати спільні підприємства з підприємствами країн Європейського Союзу у важливих для України галузях промисловості (у тому числі й в оборонній сфері) та дозволяти їм приймати участь у тендерних закупівлях.

Висновки та пропозиції. Перспективним напрямом розвитку публічних закупівель в Україні повинно стати удосконалення системи Prozorro та доповнення іï різними формами громадського контролю за проведенням цих закупівель на всіх рівнях. Проблемою в Україні є те, що поки у нашій країні недостатньо поширеною практикою $є$ здійснення контрольних заходів у сфері публічних закупівель. Цьому заважає недостатня фінансова грамотність більшості громадян, яку треба підвищувати за рахунок розвитку всіх можливих форм навчання. Підвищення ефективності використання публічних фінансів в Україні вимагає й суттєвого удосконалення підготовки кадрів у бюджетних організаціях, які формують публічні запити, оскільки багато з них не мають належної освіти і досвіду. Для посилення бюджетного контролю у сфері публічних закупівель було б доцільним ширше використовувати нецінові критерії, які вимірюються не лише показником різниці між очікуваною вартістю закупівлі, але й екологічністю предмету закупівлі у широкому розумінні слова. Перспективним напрямом регулювання публічних закупівель може стати удосконалення механізму визначення витрат при оцінці вартості життєвого циклу товару. Загалом, механізм здійснення публічних закупівель в Україні необхідно достосовувати до вимог $Є С$, що дозволить нашій країні в майбутньому ставити питання щодо вступу в цю організацію. Крім того, в документі про локалізацію в Україні наголос потрібно зробити на використанні насамперед нецінових параметрів публічних закупівель, передусім на використанні відновної енергії при виробництві тих чи інших товарів.

\section{Джерела та література}

1.Винокуров Я. Зашморг на шиї людства: як Україна разом із світом падає у боргову яму. URL: https://www.epravda.com.ua/publications/2021/06/8/674746/

2.Марчак Я., Маркуц Ю. Гаманець на три роки: скільки отримає і витратить Україна до 2024 p. URL: https://www.epravda.com.ua/publications/2021/06/7/674717/

3. Owsiak S. Finanse publiczne. Teoria i praktyka. Warszawa: WNPWN, 2001. $562 \mathrm{~s}$.

4. Osiatynski J. Finanse publiczne. Ekonomia I polityka. Warshawa: WNPWN, 2006. $310 \mathrm{~s}$.

5. E. Malinowska-Misiang, W. Misiang. Finanse publiczne w Polsce. Warszawa: WP Lexis Nexis, 2007. 732 s.

6. Конащук Н. Е. Фінансовий контроль у сфері публічних закупівель. Автореф. дис... к. е. н. за спеціальністю 08.00.08. - гроші, фінанси і кредит. Київ: КНЕУ імені Вадима Гетьмана, 2019. 20 с.

7. Парфенюк О. План п'ятиріччя: що вдалося за п'ять років. URL://www.epravda.com.ua/columns/2021/04/19/673140/

8. Forum Zakupki: обране. Частина 3. Як замовнику використовувати у закупівлях вартість життєвого циклу. URL: education.zakupki.prom.ua/ru/forum-zakupki-obrane-chastyna-3-yak-zamovnyku-vykorystovuvaty-uzakupivlyax-vartist-zhyttyevogo-chyklu/

9. «Зелені» перегони. Як Україні не втратити доступ до ринку $\mathrm{CC}$. URL: https://www.epravda.com.ua/projects/ekopromyslovist/2021/02/26/671344/

10. Стащук О.В. Бюджетна ефективність територій в умовах децентралізації. Економічний часопис ВНУ імені Лесі Украӥнки, 2021. № 1 (25), С. 98 - 104.

11. Задворний В. 43 млрд грн економії на рік. Ефект прозорих закупівель для країни. URL://www.epravda.com.ua/columns/2021/01/6/669779/

12. Яременко С. Контроль публічних закупівель. Досвід для України. URL: https://dozorro.org/blog/kontrolpublichnih-zakupivel-dosvid-polshi-dlya-ukrayini

13. Омельченко О. Операція локалізація: чим небезпечний обраний Україною шлях захисту нацвиробника. URL: https://www/eurointegration.com.ua/experts/2020/07/23/711467/ 
14. Karlin M., Batiuk O. (2021). Fiscal decentralization in the countries of the Visegrad group and Ukraine: a comparative analysis. Visegrad jornal on human rights. № 1. 2021. S. 155-162.

\section{References}

1.Vynokurov Ya. (2021). Zashmorh na shyi liudstva: yak Ukraina razom iz svitom padaie u borhovu yamu. [Zashmorg on the neck of mankind: how Ukraine together with the world falls into a debt pit.] URL: https://www.epravda.com.ua/publications/2021/06/8/674746/[in Ukrainian]

2. Marchak Ya., Markuts Yu. (2021). Hamanets na try roky: skilky otrymaie i vytratyt Ukraina do 2024 r. [Purse for three years: how much will Ukraine receive and spend by 2024] URL: https://www.epravda.com.ua/publications/2021/06/7/674717/[in Ukrainian]

3. Owsiak S. (2001). Finanse publiczne. Teoria i praktyka. Warszawa: WNPWN, 2001. 562 s. [in Poland]. Poland].

4. Osiatynski J. (2006). Finanse publiczne. Ekonomia I polityka. Warshawa: WNPWN, 2006. 310 s. [in

5.E. Malinovska-Misiag, W. Misiag. (2007). Finanse publiczne w Polsce. Warshawa: WP LexisNexis, 2007. 732 s. [in Poland].

6. Konashchuk N. E. (2019). Finansovyi kontrol u sferi publichnykh zakupivel. [Financial control in the field of public procurement]. Avtoref. dys... k. e. n. za spetsialnistiu 08.00.08. - hroshi, finansy i kredyt. Kyiv: KNEU imeni Vadyma Hetmana, 2019. 20 s. [in Ukrainian].

7. Parfeniuk O. (2021). Plan piatyrichchia: shcho vdalosia za piat rokiv. [Five-year plan: what has been achieved in five years.] URL://www.epravda.com.ua/columns/2021/04/19/673140/ [in Ukrainian].

8. Forum Zakupki: obrane. Chastyna 3. Yak zamovnyku vykorystovuvaty u zakupivliakh vartist zhyttievoho tsyklu. [How the customer to use the value of the life cycle in procurement.] URL: education.zakupki.prom.ua/ru/forum-zakupki-obrane-chastyna-3-yak-zamovnyku-vykorystovuvaty-u- zakupivlyaxvartist-zhyttyevogo-chyklu/ [in Ukrainian].

9. «Zeleni» perehony. Yak Ukraini ne vtratyty dostup do rynku YeS. ["Green" race. How can Ukraine not lose access to the EU market?] URL: https://www.epravda.com.ua/projects/ekopromyslovist/2021/02/26/671344/ [in Ukrainian].

10. Stashchuk O. (2021). Budget efficiency of territories within the decentralization. Economic Journal of Lesya Ukrainka Volyn National University, 1 (25). P. 98-104 [in Ukrainian].

11. Zadvornyi V. 43 mlrd hrn ekonomii na rik. Efekt prozorykh zakupivel dlia krainy. [43 billion UAH of savings per year. The effect of transparent procurement for the country] URL://www.epravda.com.ua/columns/2021/01/6/669779/ [in Ukrainian].

12.Iaremenko S. Kontrol publichnykh zakupivel. Dosvid dlia Ukrainy. [Control of public procurement. Experience for Ukraine] URL: https://dozorro.org/blog/kontrol-publichnih-zakupivel-dosvid-polshi-dlya-ukrayini [in Ukrainian].

13. Omelchenko O. Operatsiia lokalizatsiia: chym nebezpechnyi obranyi Ukrainoiu shliakh zakhystu natsvyrobnyka. [Operation localization: how dangerous is the way chosen by Ukraine to protect the national producer]. URL: https://www/eurointegration.com.ua/experts/2020/07/23/711467/ [in Ukrainian].

14.Karlin M., Batiuk O. (2021). Fiscal decentralization in the countries of the Visegrad group and Ukraine: a comparative analysis. Visegrad jornal on human rights. № 1. 2021. S. 155-162. [in Ukrainian].

Стаття надійшла до редакції 17.05.2021 р. 